\title{
Induction of Fingerroot (Boesenbergia Pandurata Roxb.) Buds in Various MS Media and Sucrose
}

\author{
Liberty Chaidir $^{1}$, Epin Pinasti ${ }^{2}$, Noladhi Wicaksana ${ }^{3}$ Dikayani $^{4}$ \\ \{libertychaidir@uinsgd.ac.id', pinastifebruari@gmail.com²,noladhi@unpad.ac.id ${ }^{3}$, \\ dikayani@fst.uinsgd.ac.id ${ }^{4}$ \}
}

Faculty of Science and Technology, UIN Sunan Gunung Djati Bandung ${ }^{1}$

\begin{abstract}
Fingerroot, belongs to the Zingiberaceae family, is a rhizome plant which has the characteristics of a rhizome growing vertically downward. Fingerroot contains panduratin A compound which has biological effects, such as analgesics, anticancer, antiinflammatory, and antioxidants. Fingerroot production decreased by $24.46 \%$ from $2014-$ 2016. This constraint is caused due to the decrease in the supply of its and because nurseries only rely on yields so that propagation is done through tissue culture. The purpose of this study is to determine the effect of MS media and sucrose on the growth of fingerroot buds in vitro so as to increase fingerroot production. This research was conducted in the Laboratory of Horticultural and Various Plant Seed Development Center Pasir Banteng. The method used in this study is a complete random design consisting of 2 factors, the first factor is MS media ( $1 / 4 \mathrm{MS}, 1 / 2 \mathrm{MS}$ dan $1 \mathrm{MS})$ and the second factor is sucrose $\left(15 \mathrm{gL}^{-1}, 20\right.$ $\left.\mathrm{gL}^{-1}, 25 \mathrm{gL}^{-1}\right)$, repeated 3 times. The results showed that $1 / 4 \mathrm{MS}$ and $20 \mathrm{gL}^{-1}$ sucrose media produced a growth response of healthy and green fingerroot buds with $1.2 \mathrm{~cm}$ height.
\end{abstract}

Keywords: in vitro, MS media, sucrose, fingerroot, buds.

\section{Introduction}

Fingerroot is a rhizome plant of the Zingiberaceae family which grows vertically downward. Besides being used as a cooking spice, fingerroot is also efficacious as a medicine [1]. Plant-based medicine has been widely developed for several modern treatments. Plants produce a variety of bioactive or natural products which are synthesized as secondary metabolite products [2]. The demand for fingerroot plants in Indonesia is quite high, in 2008 it reached 9,576 tons/year. This request is to meet the needs of herbal medicine seller, traditional medicine industry (TMI) and herbs. This is because fingerroot contains panduratin A which is metabolite compounds having biological effects [3].

The production results of fingerroot in Indonesia experienced a gradual decrease from 2014-2016 and in the last few years decreased by $24.46 \%$ [4]. The in vitro environment provides optimized conditions where explants can be induced to form the desired organ or plantlet [5]. Tissue culture techniques have been widely exploited for large-scale propagation. Plant micropropagation through tissue culture has become a significant and informative technique for producing and maintaining plant availability [6]. In vitro cultivars from many plants can accumulate various groups of plant metabolites with antioxidant activity including flavonoids [7] so that the content of panduratin A in fingerroot can be increased. Plants produced through 
micropropagation provide many export potentials and have the potential to be developed into new cultivars [6].

The key factor in tissue culture is the use of the planting media type and giving the appropriate concentration to the media. The concentration difference in media can affect the growth and development of explants planted in vitro. MS media are often used because they contain complete macro and micronutrients needed by explants. MS media with or without the addition of growth regulators is effective for germination or bud formation [8]. That MS media which are reduced in concentration are superior to media containing full nutrients for the growth of explants [9].

In addition to the media, carbon sources also play an important role in plant organogenesis in vitro. Exogenous carbon sources added into the media can influence organ differentiation and plant regeneration efficiency in vitro [10].

The carbon source most often used in tissue culture is sucrose, because it is the most effective carbon source compared to other types of sugars. According to the research of [10] the use of media with sucrose is most effective against plant induction. [11] mention the concentration of sucrose influences the continuity of cell growth, besides that [12] said that sucrose plays an important role in the induction of cells and energy sources.

\section{Materials And Methods}

\subsection{Time and Place of Research}

This research was conducted from March 2018 to February 2019 in the Laboratory of Horticultural and Various Plant Seed Development Center Pasir Banteng, Sumedang Regency.

\subsection{Materials and Research Tools}

The materials used are fingerroot buds, sterile aquades, $70 \%$ alcohol, MS media, sucrose and agar. Tools used include petri dishes, hand sprayers, culture bottles, autoclaves, scales, $\mathrm{pH}$ meters, spatulas, magnetic stirrers, stoves, pans, autoclaves, Bunsen burner, scalpels, tweezers, cameras and stationery.

\subsection{Experimental Design}

Experimental design consists of 2 factors, namely MS media and sucrose. Each consists of 3 different levels and combined into 9 treatments with 3 replications to obtain 27 experimental units.

Table 1. Combination of Treatment Levels

\begin{tabular}{cccc}
\hline $\begin{array}{c}\text { Concentration Level of } \\
\text { Media MS (m) }\end{array}$ & \multicolumn{3}{c}{$\begin{array}{c}\text { Concentration Level of } \\
\text { Sucrose (s) }\end{array}$} \\
\cline { 2 - 4 } & $\mathrm{s}_{1}$ & $\mathrm{~s}_{2}$ & $\mathrm{~s}_{3}$ \\
\hline $\mathrm{m}_{1}$ & $\mathrm{~m}_{1} \mathrm{~s}_{1}$ & $\mathrm{~m}_{1} \mathrm{~s}_{2}$ & $\mathrm{~m}_{1} \mathrm{~s}_{3}$ \\
$\mathrm{~m}_{2}$ & $\mathrm{~m}_{2} \mathrm{~s}_{1}$ & $\mathrm{~m}_{2} \mathrm{~s}_{2}$ & $\mathrm{~m}_{2} \mathrm{~s}_{3}$ \\
$\mathrm{~m}_{3}$ & $\mathrm{~m}_{3} \mathrm{~S}_{1}$ & $\mathrm{~m}_{3} \mathrm{~s}_{2}$ & $\mathrm{~m}_{3} \mathrm{~s}_{3}$ \\
\hline
\end{tabular}

Note: $\mathrm{m} 1=1 / 4 \mathrm{MS} ; \mathrm{m} 2=1 / 2 \mathrm{MS} ; \mathrm{m} 3=$ full MS; $\mathrm{s} 1=15 \mathrm{gL}-1$ sucrose; $\mathrm{s} 2=$

$20 \mathrm{gL}-1$ sucrose; s3 = $25 \mathrm{gL}-1$ sucrose 
The research results were analyzed by qualitative and quantitative methods, through counting the growth of buds including bud height and color.

\section{Results And Discussion}

\subsection{Bud Height}

Each explant which experienced growth was marked by the increase of bud height. Based on the observed bud height, $\mathrm{m}_{1} \mathrm{~s}_{2}$ media treatment gave the best height growth results, this observation can be seen in the bud height growth data presented in Table 2.

Table 2. The concentration effect of MS media and sucrose on growth of bud height on fingerroot explants at 2-8 WAI

\begin{tabular}{cccccccccc}
\hline $\begin{array}{c}\text { Explant } \\
\text { age }\end{array}$ & \multicolumn{8}{c}{ Bud height $(\mathrm{cm})$} \\
\cline { 2 - 10 }$(\mathrm{WAI})$ & $\mathrm{m}_{1} \mathrm{~s}_{1}$ & $\mathrm{~m}_{1} \mathrm{~s}_{2}$ & $\mathrm{~m}_{1} \mathrm{~S}_{3}$ & $\mathrm{~m}_{2} \mathrm{~S}_{1}$ & $\mathrm{~m}_{2} \mathrm{~S}_{2}$ & $\mathrm{~m}_{2} \mathrm{~S}_{3}$ & $\mathrm{~m}_{3} \mathrm{~s}_{1}$ & $\mathrm{~m}_{3} \mathrm{~s}_{2}$ & $\mathrm{~m}_{3} \mathrm{~S}_{3}$ \\
\hline 2 & 0.2 & 0.3 & 0.3 & 0.5 & 0.4 & 0.3 & 0.3 & 0.3 & 0.5 \\
4 & 0.2 & $0.6^{*}$ & 0.3 & 0.5 & 0.4 & 0.6 & 0.5 & 0.3 & 0.5 \\
6 & 0.2 & $0.9^{*}$ & 0.3 & 0.5 & 0.4 & 0.7 & 0.7 & 0.3 & 0.5 \\
8 & 0.2 & $1.2^{*}$ & 0.3 & 0.5 & 0.4 & 0.7 & 0.9 & 0.3 & 0.5 \\
\hline
\end{tabular}

Note: $\mathrm{WAI}=$ Week After Initiation; * = significant change

Based on the research results, explants began to show a growth response at 2 WAI. In $\mathrm{m}_{1} \mathrm{~s}_{2}$ explants, the bud height increase was very significant, the average height increase occurring at each observation was $0.3 \mathrm{~cm}$. The change in height can be seen in Figure 1. 


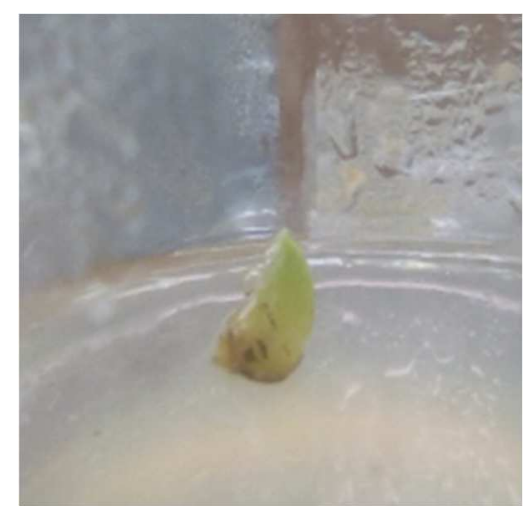

A

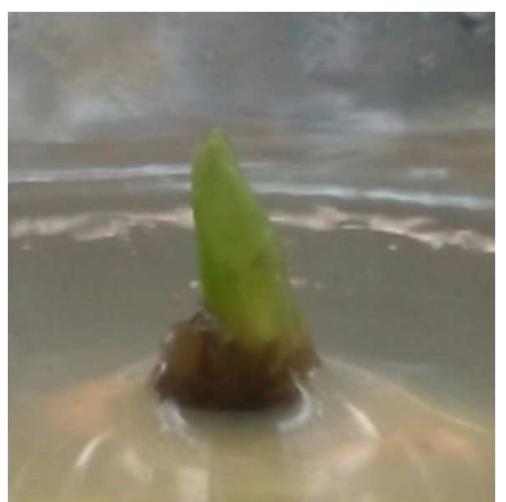

B

Figure 1. Fingerroot bud height increase

$$
\begin{aligned}
& \text { a. At } 2 \text { WAI } \\
& \text { b. At } 8 \text { WAI }
\end{aligned}
$$

The combination of MS media and sucrose on the media can influence the growth patterns of fingerroot explants. Based on observations of all explants that experienced growth, it is known that the time needed to show the growth response was at 2 WAI. The explant of m1s2 shows the best growth of bud height because the treatment contains sufficient nutrients and an optimal carbon source. The $1 / 4$ MS treatment became more easily absorbed by explants, and 20 $\mathrm{g} \mathrm{L}^{-1}$ sucrose was able to provide an energy source for explant growth. In addition, the age of explants grown in the $\mathrm{m} 1 \mathrm{~s} 2$ treatment $(0.3 \mathrm{~cm}$ at $2 \mathrm{WAI})$ was relatively older than the $\mathrm{m}_{1} \mathrm{~s}_{1}$ explants $(0.2 \mathrm{~cm}$ at $2 \mathrm{MSI})$, so the growth process was generally relatively faster. However, compared to other treatments which had uniform bud height at $2 \mathrm{WAI}$, the $\mathrm{m}_{1} \mathrm{~s}_{2}$ treatment was still superior. Sucrose is the most effective carbon for bud induction and bud proliferation [5].

Formation and growth of buds are the main objectives of this study. Explained that a bud is a new plant which will grow from the plant parts [13]. The growth of buds is important in the cultivation of tissue culture because buds are the part which is used in the next propagation process. Micro bud culture must be tested because highly different cells in in-vitro systems have high growth potentials and can produce high active metabolite compounds [14].

The success of tissue culture is determined by tissue culture media which is the place to grow for explants. MS media are mostly chosen as media in the multiplication of tissue culture because it has complete micro and macronutrient content. However, explants cannot absorb these nutrients if carbohydrates are not available in the media. In tissue culture, explants do not undergo photosynthesis, so they require additional carbohydrates to meet their energy needs. Therefore, sucrose plays an important role in the process of tissue culture, especially for the growth of shoots. The addition of sucrose to the media with optimal concentration will meet the energy requirements for cells to grow optimally [15]. If the carbon source is sufficient, the cells will be formed properly so that the explants are able to grow buds. That $1 / 2$ MS affects the proliferation of ginger buds [16] and that the concentration $20 \mathrm{~g} \mathrm{~L}^{-1}$ sucrose is the best concentration for buds produced in red ginger buds [17].

\subsection{Bud Color}


Based on observations, bud growth began with a change in color. The growing explants initially were pink, and then turned green after being cultured. This color change indicates that the explant has absorbed nutrients in the culture media, resulting in cell development in the explant body. These color changes can be seen in Figure 2.

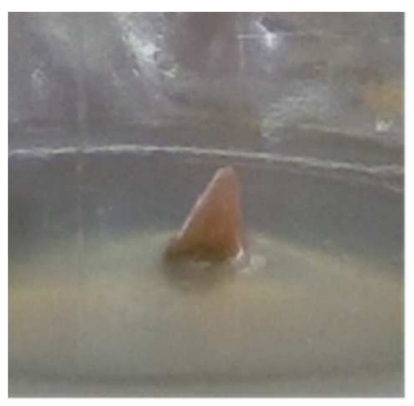

A

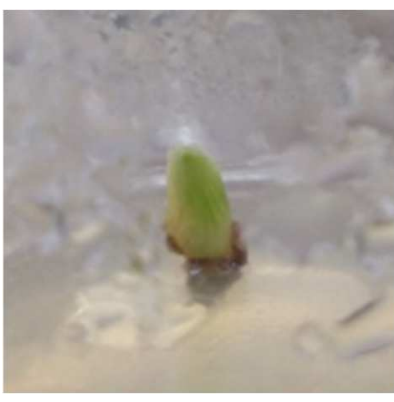

B

Figure 2. Bud color change

a. Before growing

b. After growing

The conducted shoot color observations were based on Munsell's plant tissue color book (2012) version, while the color changes are presented in Table 3.

Table 3. Concentration effect on media MS dan sucrose in fingerroot explant color change in 2-8 WAI.

\begin{tabular}{|c|c|c|c|c|}
\hline \multirow{2}{*}{ Treatment } & \multicolumn{4}{|c|}{ Explant Age (WAI) } \\
\hline & 2 & 4 & 6 & 8 \\
\hline $\mathrm{m}_{1} \mathrm{~s} 1$ & $7.5 \mathrm{GY} 6 / 6$ & $7.5 \mathrm{GY} 6 / 4$ & $7.5 \mathrm{GY} 7 / 10$ & $7.5 \mathrm{GY} 5 / 4$ \\
\hline $\mathrm{m}_{1} \mathrm{~s}_{2}$ & $2.5 \mathrm{GY} 8 / 4^{*}$ & $5 \mathrm{GY} 7 / 4^{*}$ & $5 \mathrm{GY} 7 / 8^{*}$ & $5 \mathrm{GY} 5 / 10^{*}$ \\
\hline $\mathrm{m}_{1} \mathrm{~s}_{3}$ & $2.5 \mathrm{Y} 7 / 2$ & $2.5 \mathrm{Y} 8 / 2$ & $5 \mathrm{Y} 8 / 2$ & $2.5 \mathrm{Y} 8 / 2$ \\
\hline $\mathrm{m}_{2} \mathrm{~s}_{1}$ & $5 Y 7 / 2$ & $5 Y 7 / 2$ & $2.5 \mathrm{Y} 7 / 4$ & $2.5 \mathrm{Y} 7 / 2$ \\
\hline $\mathrm{m}_{2} \mathrm{~s}_{2}$ & $2.5 Y 6 / 4$ & $5 Y 7 / 2$ & $2.5 Y 5 / 4$ & $7.5 Y R 4 / 2$ \\
\hline $\mathrm{m}_{2} \mathrm{~s}_{3}$ & 5YR 5/4 & $5 Y R 6 / 2$ & $2.5 \mathrm{GY} 7 / 6$ & $5 Y 5 / 4$ \\
\hline $\mathrm{m}_{3} \mathrm{~s}_{1}$ & $2.5 \mathrm{GY} 7 / 2$ & $2.5 \mathrm{GY} 7 / 6$ & $2.5 \mathrm{GY} 7 / 6$ & $2.5 \mathrm{GY} 7 / 8$ \\
\hline $\mathrm{m}_{3} \mathrm{~s}_{2}$ & $2.5 Y 7 / 4$ & $2.5 Y 7 / 2$ & $2.5 Y 7 / 4$ & 7.5 YR 5/4 \\
\hline $\mathrm{m}_{3} \mathrm{~s}_{3}$ & $5 Y 8.4$ & $5 Y 8 / 6$ & $5 Y 6 / 4$ & $5 Y 5 / 4$ \\
\hline Note: & $\begin{array}{l}\text { WAI = Week } \\
\mathrm{N} \mathrm{H} / \mathrm{C} \text { à } \mathrm{N}=\mathrm{c} \\
\mathrm{G}=\text { green; } \mathrm{Y}= \\
\mathrm{GY}=\text { green-y } \\
*=\text { the best co }\end{array}$ & $\begin{array}{l}\text { itiation } \\
\text { ue; } \mathrm{H}=\text { hue } \\
; \mathrm{R}=\text { red à c } \\
\mathrm{R}=\text { yellow-1 }\end{array}$ & $\begin{array}{l}=\text { chroma val } \\
\text { omatic colors } \\
\text { ed the subdiv }\end{array}$ & romatic color \\
\hline
\end{tabular}


Based on observations made using the Munsell's book (2012 version), explants that experienced the best color change were in $\mathrm{m} 1 \mathrm{~s} 2$ treatment ( $1 / 4 \mathrm{MS}$ and $20 \mathrm{~g} \mathrm{~L}^{-1}$ sucrose media), when at $2 \mathrm{WAI}$, the explants had green pigments at the tip of the bud. Based on Munsell's book (2012 version) $\mathrm{m}_{1} \mathrm{~s}_{2}$ explant ( $1 / 4 \mathrm{MS}$ and $20 \mathrm{~g} \mathrm{~L}^{-1}$ sucrose media) on $2 \mathrm{WAI}$ has a color of $2.5 \mathrm{GY}$ $6 / 2$, chromatic color with Green-Yellow (GY) subdivision, which means that it formed chlorophyll b pigment $\left(\mathrm{C}_{55} \mathrm{H}_{70} \mathrm{O}_{6} \mathrm{~N}_{4} \mathrm{Mg}\right.$ ), and brightness level (light value $=6$ ) above neutral or near pure white and color saturation strength (chroma notation $=2$ ) which means fade. The $\mathrm{m}_{1} \mathrm{~s}_{2}$ treatment ( $1 / 4 \mathrm{MS}$ and $20 \mathrm{~g} \mathrm{~L}^{-1}$ sucrose media) at $4 \mathrm{MSI}$ showed buds that grew greener with color code $5 \mathrm{GY} 7 / 4$, chromatic color with Green-Yellow (GY) sub-division with brightness (light value $=7$ ) relatively lighter and the strength of color saturation (chroma notation $=4$ ) is not too faded. This happens because the chlorophyll contained in explants increases in number as incubation time passes. At $6 \mathrm{WAI}$, the m1s 2 treatment ( $1 / 4 \mathrm{MS}$ and $20 \mathrm{~g} \mathrm{~L}^{-1}$ sucrose media) showed a color of $5 \mathrm{GY} 7 / 8$, with the same color notation and color saturation strength (chroma notation $=8$ ) which means concentrated. Similar to leaves on plants, mature leaves will look greener than young leaves. At $8 \mathrm{WAI}$, the $\mathrm{m}_{1} \mathrm{~s}_{2}$ treatment $\left(1 / 4 \mathrm{MS}\right.$ and $20 \mathrm{~g} \mathrm{~L}^{-1}$ sucrose media) had a $5 \mathrm{GY} 5 / 10$ color indicating that the chlorophyll content increased with brightness (light value $=5$ ) which was not too bright or neutral between pure white and pure black, whereas color saturation strength (chroma notation $=10$ ) which means concentrated, meaning that this color indicates a greener color than before.

There are several factors which influence the formation of chlorophyll in plants including light, oxygen, water, carbohydrates and temperature. The light observed in this study was conducted at the beginning of the culture using flourescent lamps with a power of 40 watts. The intensity of the light absorbed up to the culture bottle is 600-800 lux. However, each plant had different capabilities in absorbing light. The greener the color of the plant, the more chlorophyll the plant has. In this condition, explants experiencing growth have different abilities in capturing light. Under the same lighting conditions, the color of the shoots varies, showing that this difference is not caused by light factors.

Environmental temperature plays a role in the formation of chlorophyll in plants, a good temperature for the formation of chlorophyll is between $3{ }^{\circ} \mathrm{C}$ and $48^{\circ} \mathrm{C}$ [18]. In this study, the average daily temperature was $23.22^{\circ} \mathrm{C}$, indicating that the temperature was stable for the formation of chlorophyll in plants. Each explant has different chlorophyll formation at the average temperature. This is due to other factors which trigger the difference in color changes.

Nutrient content in the planting media is very influential on the growth of explants. Differences in nutrient content cause different growths in explants, one of which is the formation of chlorophyll. MS media contain macro and micronutrients needed by plants. The nutrient element most needed for the formation of chlorophyll is Magnesium $(\mathrm{Mg})$. The presence of $\mathrm{Mg}$ in the media can increase phosphate content in plants. In addition, $\mathrm{Mg}$ plays an important role in the formation of chlorophyll in plants. Other nutrients such as Nitrogen $(\mathrm{N})$, Potassium $(\mathrm{K})$, Phosphorus (P) and Sulfur (S) can also affect the color of explants if a deficiency occurs. States that MS media containing $69 \mathrm{mM}$ of $\mathrm{N}$ in the form of $\mathrm{NO}_{3}$ and $\mathrm{NH}_{4}{ }^{+}$. The $\mathrm{N}$ content is higher than the $\mathrm{N}$ content found in Miller, Hildebrant and White media [19]. Therefore, the use of MS media with low concentrations is able to meet the nitrogen requirements needed by explants.

Based on observations, a good concentration for the formation of chlorophyll is $\mathrm{m} 1(1 / 4 \mathrm{MS}$ media) with s2 (20 $\mathrm{g} \mathrm{L}^{-1}$ sucrose). The use of $1 / 4 \mathrm{MS}$ media is able to meet the nutrient requirements needed for the growth of fingerroot buds, when combined with $20 \mathrm{~g} \mathrm{~L}^{-1}$ sucrose. The use of sucrose with a concentration of $20 \mathrm{~g} \mathrm{~L}^{-1}$ is able to meet the carbon requirements needed by explants in the formation and growth of buds. The appropriate combination of MS media and sucrose can produce the best bud color, while the $m_{3} s_{1}$ treatment with full MS media 
concentration and sucrose $15 \mathrm{~g} \mathrm{~L}^{-1}$. Although the availability of nutrient sources is quite high, the sucrose content is lower. Therefore, this produces less chlorophyll, coded 2.5GY which means it has a dominant yellow chromatic color. This is in line with research conducted by [20] which states that sucrose affects the amount of chlorophyll in explants, the higher the sucrose concentration, the more chlorophyll the explants have.

The color change of the buds to green indicates the presence of chlorophyll in the tissue. Mardini (2015) explained that the density of green in plants indicates the amount of chlorophyll content of plants. Chlorophyll is a green pigment which is located in the chloroplast, where plants conduct photosynthesis. Green buds indicate that the growth of these shoots is undergoing well. Media concentrations $1 / 4 \mathrm{MS}$ and $20 \mathrm{~g} \mathrm{~L}^{-1}$ sucrose used are able to show an optimal shoot growth.

\section{Conclusion And Suggestion}

The best combination of MS media and sucrose for the growth of fingerroot buds in vitro is the combination of medium treatment of $1 / 4 \mathrm{MS}+20 \mathrm{~g} \mathrm{~L}^{-1}$ sucrose. The concentration is able to grow healthy and green shoots with a height of $1.2 \mathrm{~cm}$.

Further research is needed to find out more precise concentrations and the addition of growth regulators to produce explants with more optimal regeneration abilities.

\section{References}

[1] W. Yulianti, Indrian, N. Juniati, T. P. Raharjo, B. N. Utami, and F. Kharisma, "Pengembangan Tanaman Obat Temu Kunci," 2016.

[2] M. Akshatha, S. Kavadikeri, and N. Rao, "In vitro Micropropagation and Antioxidant Assay in Colocasia esculenta. Plant Tissue Culture \& Biotechnology," Plant Tissue Cult. Biotechnol., vol. 28, no. 2, pp. 183-190, 2018.

[3] D. Kusbiantoro and Y. Purwaningrum, "No Title," Kultivasi, vol. 17, no. 1, pp. 544-549, 2018.

[4] B. P. S. dan D. J. Hortikultura, "Produksi Biofarmaka di Indonesia Tahun 2012-2016," 2016.

[5] J. A. Teixeira da Silva, S. Zeng, G. Godoy-Hernández, R. Rivera-Madrid, and J. Dobránszki, "Bixa orellana L. (achiote) tissue culture: a review," Vitr. Cell. Dev. Biol. - Plant, vol. 55, no. 3, pp. 231-241, 2019.

[6] M. Paul, T. Islam, R. Sarker, and M. I. Hoque, "In Vitro Mass Propagation of Cymbidium aloifolium (L.) Sw," Plant Tissue Cult. Biotechnol., vol. 23, no. 1, pp. 73-79, 2019.

[7] I. Kwiecień, J. Smolin, L. Beerhues, and H. Ekiert, "The impact of media composition on production of flavonoids in agitated shoot cultures of the three Hypericum perforatum L. cultivars 'Elixir,' 'Helos,' and 'Topas,'” Vitr. Cell. Dev. Biol. - Plant, vol. 54, no. 3, pp. 332-340, 2018.

[8] B. Pant and S. Swar, "Micropropagation of Cymbidium iridioides," Nepal J. Sci. Technol., vol. 12, pp. 91-96, 2011.

[9] M. K and R. B, "The Effect of Activated Charcoal Supplemented Media to Browning of in Vitro Cultures of Piper Spices," Biol. Plantrum, vol. 43, pp. 297-299, 2002.

[10] M. Dreger, R. M, A. D, E. R, G. M, and K. W., "Improved Plant Regeneration in Callus Cultures of Shorgum bicolor (L.) Moench," The Netherlands, vol. 55, pp. 190-198, 2018.

[11] W. Dewitte and J. Murray, Meristematic Tissues in Plant Growth and Development. London: Sheffield Academic Press, 2002.

[12] P. B. Gahan, Totipotency and the cell cycle. In Jain, S.M. and H. Häggman (eds). Protocols for Micropropagation of Woody Trees and Fruits. The Netherland: Springer, 2007. 
[13] N. Leduc et al., "Light Signaling in Bud Outgrowth and Branching in Plants," Plants, vol. 3, no. 2, pp. 223-250, 2014.

[14] D. K, B. Nikola Damianova, R. Denev, and D. Dimitrov, "Influences of Vitamin on Polyphenolic Content, Morphological Development, and Stress Response in Shoot Cultures of Hypericum spp," Plant Tissue Cult. Organ Cult. 110 383-393., vol. 110, pp. 383-393, 2012.

[15] E. N. Sitorus, E. D. Hastuti, and N. Setiari., "Induksi Kalus Binahong (Basella ruba L.) secara in Vitro pada Media Murashige dan Skoog dengan Konsentrasi Sukrosa yang Berbeda,” J. Bioma, vol. 13, no. 1,2011

[16] Kristina, "Produksi Rimpang Temu Hitam (Curcuma aeruginaosa) melalui kultur in Vitro," Infotek Perkeb., vol. 16, no. 1, 2014.

[17] T. M. Ermayanti, E. A. H. Dan, and B. W. Hapsari, "Kultur Jaringan Jahe Merah (Zingiber officinale Rosc.) pada Media Sederhana Sebagai Upaya Konservasi secara in Vitro," J. Berk Panel Hayati., vol. 4, pp. 83-89, 2010.

[18] M. Pritts, Foliar Testing and Sampling in Berry Crops, Visual Symptoms of Deficiencies. Cornell University, 2018.

[19] M. A. B. Purwono, Arya Rezagama, Muhammad Hibbaan, "Ammonia-Nitrogen (NH3-N) and Ammonium-Nitrogen (NH4+-N) Equilibrium on The Process of Removing Nitrogen By Using Tubular Plastic Media,” J. Mater. Environ. Sci, vol. 8, no. s, pp. 4915-4922, 2017.

[20] A. Silvia, "Variasi Konsentrasi Sukrosa Dan Panjang Gelombang Cahaya Terhadap Pertumbuhan dan Kandungan Klorofil Tanaman Nilam (Pogostemon Cablin Benth.) Secara In Vitro," J. Agritech, vol. 12, no. 11, pp. 22-34. 